\title{
Determination of Antioxidant and Oxidant Potentials of Thymbra spicata Collected from Duhok-Iraq
}

\author{
Falah Saleh Mohammed ${ }^{1, a, *}$, Ali Erdem Şabik ${ }^{2, b}$, Emre Sevindik $^{3, c}$, Mustafa Pehlivan $^{4, d}$, Mustafa Sevindik ${ }^{5, f}$

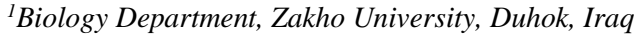 \\ ${ }^{2}$ Department of Chemistry and Chemical Processing Technologies, Bahçe Vocational School, Osmaniye Korkut Ata University, 80010 \\ Osmaniye, Turkey \\ ${ }^{3}$ Department of Agricultural Biotechnology, Faculty of Agriculture, Adnan Menderes University, 09010 Aydin, Turkey \\ ${ }^{4}$ Nurdagl Vocational School, Gaziantep University, Gaziantep, Turkey \\ ${ }^{5}$ Department of Food Processing, Bahçe Vocational School, Osmaniye Korkut Ata University, 80010 Osmaniye, Turkey \\ *Corresponding author
}

\begin{tabular}{l|l} 
A R T I C L E I N F O & A B S T R A C T \\
\hline Research Article & $\begin{array}{l}\text { In this study, antioxidant, oxidant and oxidative stress index of Thymbra spicata } \mathrm{L} . \text { collected from } \\
\text { Duhok (Iraq) region were determined. The aerial parts of the plant were extracted with ethanol. Rel } \\
\text { Assay Diagnostics kits were used for detect TAS, TOS and OSI values. As a result of the studies, it } \\
\text { was determined that TAS value of plant extract was determined } 8.399 \pm 0.102, \text { TOS value was }\end{array}$ \\
$\begin{array}{l}\text { Received : } 26 / 01 / 2020 \\
\text { Accepted : } 16 / 03 / 2020\end{array}$ & antioxidant potential and in this context, can be used as a natural resource.
\end{tabular}

Keywords:

Antioxidant

Medicinal plants

Oxidative stress

Thymbra spicata Iraq

\section{A B S T R A C T}

Duhok (Iraq) region were determined. The aerial parts of the plant were extracted with ethanol. Rel

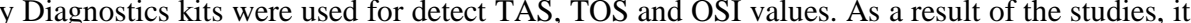

falah.sindy@uoz.edu.krd ph.d-emre@hotmail.com sevindik27@gmail.com

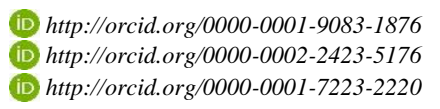
b@erdemsabik@osmaniye.edu.tr
d@ pehlivan@gantep.edu.tr

(iD http://orcid.org/0000-0001-6182-3834 (iD) http://orcid.org/0000-0002-8277-6085

\section{Introduction}

Despite the increasing human population, complementary medicine orientation is gradually increasing due to the insufficient health services in many countries. The use of plants in complementary medicine for different purposes dates back to very old times (Kam and Liew, 2002; Ondua et al., 2019). In addition to their use as food, plants have been used for many purposes such as taste and fragrance, medicine, shelter construction, firewood and weapon making from past to present. In addition, extracts prepared from herbs called medicinal plants have been used in the treatment of many diseases (Shyur et al., 2005; Kılıç et al., 2017). After the beginning of the 19th century, drugs started to be made using the active substances found in the plants and the pharmaceutical industry was born. In addition to all these developments, especially in recent years, interest in treatment methods with herbal origin extracts has been increasing day by day. The reason for this is thought to be due to the side effects of synthetic drugs (Modak et al., 2007; Qader et al., 2011; Bozok, 2018). In this context, it is very important to determine the potential of plants as alternative drug sources.

Iraq is one of the important settlements that have hosted many civilizations. Pollen analyses conducted in neanderthal tombs discovered by Ralph Solecki and this team in Sanidar Cave, located in Northern Iraq and dated to the Middle Paleolithic Period, provided important evidence that the medicinal plants were known and used about 60 thousand years ago (Fiacconi and Hunt 2015). 
In this study, the total antioxidant status (TAS), total oxidant status (TOS) and oxidative stress index (OSI) of Thymbra spicata L. plant collected from Duhok (Iraq) were determined.

\section{Materials and Methods}

T. spicata was collected from Duhok (Iraq). The plant was diagnosed using Flora of Iraq (Townsend and Guest, 1966-1985). The plant samples collected during the field studies in the Mangesh region of Duhok. The samples were dried a dry and shady area. After drying, the aerial parts (leaves, flowers and partly stems) were powdered. Then, $30 \mathrm{~g}$ of plant samples were cartridges and extraction process was carried out with ethanol $(\mathrm{EtOH})$ in the soxhlet extractor during approximately 6 hours at $50^{\circ} \mathrm{C}$. The extracts obtained were concentrated with a rotary evaporator (Heidolph Laborota 4000 Rotary Evaporator).

\section{Determination of TAS, TOS and OSI Values}

TAS, TOS and OSI values of EtOH extracts of T. spicata were determined using Rel Assay brand kits (Erel, 2004; Erel, 2005). Trolox was used as the calibrator for TAS values. Hydrogen peroxide was used as the calibrator for TOS values. OSI (Arbitrary Unit $=A U$ ) value was determined according to the following formula (Erel, 2005).

$$
\mathrm{OSI}=\frac{\mathrm{TOS}, \mu \mathrm{mol} \mathrm{H}_{2} \mathrm{O}_{2} \text { equiv./L }}{\mathrm{AS}, \mathrm{mmol} \text { Trolox equiv./L } \times 10}
$$

\section{Results and Discussion}

Traditional herbal remedies have been used in developing and developed countries for thousands of years because they are natural and cause relatively few complications. The antioxidant potential of a medicinal plant depends on the condition of clearing or suppressing reactive oxygen species in the living organism. Many studies in recent years have reported that different parts of plants have antioxidant potential (Boullata and Nace, 2000; Pandey et al., 2019). In our study, EtOH extracts of $T$. spicata were used and their antioxidant and oxidant potentials were investigated. In addition, oxidative stress index was determined based on antioxidant and oxidant states. The results obtained was shown in Table 1 .

Table 1. TAS, TOS and OSI values of T. spicata

\begin{tabular}{l|c}
\hline \multicolumn{1}{c|}{ Parameters } & T. spicata \\
\hline TAS & $8.399 \pm 0.102$ \\
TOS & $6.530 \pm 0.115$ \\
OSI & $0.078 \pm 0.001$ \\
\hline \multicolumn{2}{|c}{ Values are presented as mean \pm SD; Experiments were made in 5 parallels }
\end{tabular}

In the literature, TAS, TOS and OSI values of $T$. spicata have not been reported. In studies on different plant species, TAS values of Silybum marianum, Allium calocephalum, Rhus coriaria var. zebaria, Mentha longifolia subsp. longifolia, Rosa canina and Salvia multicaulis were reported as 5.767, 5.853, 7.342, 3.628, 4.602 and $6.434 \mathrm{mmol} / \mathrm{L}$, respectively. TOS values were reported as $12.144,16.288,5.170,4.046,6.294$ and 22.441 $\mu \mathrm{mol} / \mathrm{L}$, respectively. OSI values were reported as 0.211 , $0.278,0.071,0.112,0.138$ and 0.349 , respectively (Sevindik et al., 2017; Pehlivan and Sevindik, 2018; Mohammed et al., 2018; Pehlivan et al., 2018; Mohammed et al., 2019a; Mohammed et al., 2019b). In addition, TAS value of Thermopsis turcica was determined as $2.06 \pm 0.09$ $\mu \mathrm{mol} / \mathrm{g}$ in a different study (Aksoy et al., 2013). In another study, it was reported that TAS value of Brassica rapa was $1.25 \mathrm{mmol} / \mathrm{L}$ (Gul et al., 2013). Compared to these studies, it is seen that TAS value of $T$. spicata was higher than $S$. marianum, A. calocephalum, $R$. coriaria var. zebaria, $M$. longifolia subsp. longifolia, $R$. canina, S. multicaulis, $T$. turcica and B. rapa. These different antioxidant potentials that arise among plant samples are thought to arise from the capacity of plants to produce antioxidants. In addition, it was determined by different researchers that $T$. spicata has antioxidant potential. In these studies, it was reported that the DPPH free radical activity of ethanol extracts of the aerial parts of T. spicata was high (Khalil et al., 2019). In a different study, it was reported that methanol extracts of $T$. spicata have antioxidant potential (Ertürk et al., 2017). In another study, it was reported that the essential oils of $T$. spicata have antioxidant potentials (Bayan et al., 2017). It is seen that $T$. spicata used in our study, which was similar to these studies, was high antioxidant potential.

When TOS values were examined, it was determined that $T$. spicata had higher values than $R$. coriaria var. zebaria, $M$. longifolia ssp. longifolia ve $R$. canina and lower values than $S$. marianum, A. calocephalum, $S$. multicaulis. TOS values show all of the oxidant compounds produced by the plant as a result of metabolic activities. TOS values may vary depending on environmental factors (Selamoglu et al., 2016). This difference occurring between the TOS values of plants is thought to vary depending on the oxidant compound to be produced, the habitat of the plant and the differences of the species. In this context, it was observed that the TOS value of $T$. spicata was not high.

OSI values show how much the endogenous oxidant compounds produced by the plant are suppressed with endogenous antioxidant compounds (Dogan et al., 2014). In this context, it was determined that OSI value of $\mathrm{T}$. spicata was higher than $R$. coriaria var. zebaria and lower than S. marianum, A. calocephalum, M. longifolia ssp. longifolia, $R$. canina and $S$. multicaulis.

\section{Conclusion}

In this study, antioxidant and oxidant potentials of $T$. spicata collected from Duhok (Iraq) region were determined. As a result of the studies, it was determined that the ethanol extracts of the plant have high antioxidant potential. In addition, plant extracts were found to have low levels of oxidant. In this context, it was determined that $T$. spicata could be a natural antioxidant agent.

\section{References}

Aksoy L, Kolay E, Ağılönü Y, Aslan Z, Kargığlu M. 2013. Free radical scavenging activity, total phenolic content, total antioxidant status, and total oxidant status of endemic Thermopsis turcica. Saudi journal of biological sciences, 20(3): 235-239. 
Bayan Y, Genc N, Kusek M, Gul F, Imecik Z. 2017. Determination of Chemical Compositions, Antifungal, Antibacterial and Antioxidant Activity of Thymbra spicata L. From Turkey. Fresen Environ Bull, 26(12): 7595-7599

Boullata JI, Nace AM. 2000. Safety issues with herbal medicine. Pharmacotherapy: The Journal of Human Pharmacology and Drug Therapy, 20(3): 257-269.

Bozok F. 2018. Herbicidal Activity of Nepeta flavida Essential Oil. Journal of Essential Oil Bearing Plants, 21(6): 16871693.

Doğan H, Akyol E, Akgül H, Talas ZS. 2014. Biologic activities of honeybee products obtained from different phytogeographical regions of Turkey. Turkish Journal of Agriculture-Food Science and Technology, 2(6): 273-276.

Erel O. 2004. A novel automated direct measurement method for total antioxidant capacity using a new generation, more stable ABTS radical cation. Clinical biochemistry, 37(4): 277-285.

Erel O. 2005. A new automated colorimetric method for measuring total oxidant status. Clinical biochemistry, 38(12): 1103-1111.

Ertürk Ö, Tanrıkulu Gİ, Yavuz C, Can Z, Çakır HE. 2017. Chemical compositions, antioxidant and antimicrobial activities of the essential oil and extracts of Lamiaceae family (Ocimum basilicum and Thymbra spicata) from Turkey. International Journal of Secondary Metabolite, 4(3, Special Issue 2): 340-348.

Fiacconi M, Hunt CO. 2015. Pollen taphonomy at Shanidar Cave (Kurdish Iraq): an initial evaluation. Review of Palaeobotany and Palynology, 223: 87-93.

Gul S, Ahmed S, Gul H, Shad KF, Zia-Ul-Haq M, Badiu D. 2013. The antioxidant potential of Brassica rapa $\mathrm{L}$. on glutathione peroxidase, superoxide dismutase enzymes and total antioxidant status. Romanian Review of Laboratory Medicine, 21(2): 161-169.

Kam PCA, Liew S. 2002. Traditional Chinese herbal medicine and anaesthesia. Anaesthesia, 57(11): 1083-1089.

Khalil M, Khalifeh H, Baldini F, Salis A, Damonte G, Daher A, Voci A, Vergani L. 2019. Antisteatotic and antioxidant activities of Thymbra spicata L. extracts in hepatic and endothelial cells as in vitro models of non-alcoholic fatty liver disease. Journal of ethnopharmacology, 239: 111919.

Kılıç C, Can Z, Yılmaz A, Yıldız S, Turna H. 2017. Antioxidant properties of some herbal teas (green tea, senna, corn silk, rosemary) brewed at different temperatures. International Journal of Secondary Metabolite, 4(3, Special Issue 1): 142148 .
Modak M, Dixit P, Londhe J, Ghaskadbi S, Devasagayam TPA. 2007. Recent advances in Indian herbal drug research guest editor: Thomas Paul Asir Devasagayam Indian herbs and herbal drugs used for the treatment of diabetes. Journal of clinical biochemistry and nutrition, 40(3): 163-173.

Mohammed FS, Akgul H, Sevindik M, Khaled BMT. 2018. Phenolic content and biological activities of Rhus coriaria var. zebaria. Fresen Environ Bull, 27(8): 5694-5702.

Mohammed FS, Karakaş M, Akgül H, Sevindik M. 2019a. Medicinal Properties of Allium calocephalum Collected from Gara Mountain (Iraq). Fresen Environ Bull, 28(10): 74197426.

Mohammed FS, Pehlivan M, Sevindik M. 2019b. Antioxidant, Antibacterial and Antifungal Activities of Different Extracts of Silybum marianum Collected from Duhok (Iraq). International Journal of Secondary Metabolite, 6(4): 317-322.

Ondua M, Njoya EM, Abdalla MA, McGaw LJ. 2019. Antiinflammatory and antioxidant properties of leaf extracts of eleven South African medicinal plants used traditionally to treat inflammation. Journal of ethnopharmacology, 234: 2735.

Pandey A, Belwal T, Tamta S, Bhatt ID, Rawal RS. 2019. Phenolic compounds, antioxidant capacity and antimutagenic activity in different growth stages of in vitro raised plants of Origanum vulgare L. Molecular biology reports, 46(2): 22312241.

Pehlivan M, Sevindik M. 2018. Antioxidant and antimicrobial activities of Salvia multicaulis. Turkish Journal of Agriculture-Food Science and Technology, 6(5): 628-631.

Pehlivan M, Mohammed FS, Sevindik M, Akgul H. 2018. Antioxidant and oxidant potential of Rosa canina. Eurasian Journal of Forest Science, 6(4): 22-25.

Qader SW, Abdulla MA, Chua LS, Najim N, Zain MM, Hamdan S. 2011. Antioxidant, total phenolic content and cytotoxicity evaluation of selected Malaysian plants. Molecules, 16(4): 3433-3443.

Selamoglu Z, Akgul H, Dogan H. 2016. Environmental effects on biologic activities of pollen samples obtained from different phytogeographical regions in Turkey. Fresen Environ Bull, 25: 2484-2489.

Sevindik M, Akgul H, Pehlivan M, Selamoglu Z. 2017. Determination of therapeutic potential of Mentha longifolia ssp. longifolia. Fresen Environ Bull, 26(7): 4757-4763.

Shyur LF, Tsung JH, Chen JH, Chiu CY, Lo CP. 2005. Antioxidant properties of extracts from medicinal plants popularly used in Taiwan. Int J Appl Sci Eng, 3(3): 195-202.

Townsend CC, Guest E. 1966-1985. Flora of Iraq, Volumes 1-4, 8-9. Ministry of Agriculture and Agrarian Reform and Bentham-Moxon Trust. Baghdad, Iraq. 